\title{
HOTEL RWANDA: \\ INDIVIDUAL HEROISM OR INTERCONNECTEDNESS IN THE PORTRAYAL OF PAUL RUSESABAGINA?
}

\author{
Marthie Momberg \\ Systematic Theology \\ Stellenbosch University
}

\begin{abstract}
Why does the protagonist in the film 'Hotel Rwanda' (2004) shelter almost 1300 refugees and in the process risk his own life? Most critics say it is because Paul Rusesabagina is a hero. Yet heroism as an individual act of courage may not be the only answer. I argue that an inclusive enactment of interconnected, communal belonging opens up the possibility to understand facets of Rusesabagina's bravery as a spiritual choice. To fail to consider clues from the Rwandese society and its heritage may, even with the best of intentions to do the opposite, result in projections of the self that compound the tragedy of othering in the Rwandan genocide of 1994 when the world turned a blind eye to the massacre.
\end{abstract}

Key Words: Hotel Rwanda, Heroism; Interconnectedness; Existential Symbols;

Film Interpretation

\section{Introduction}

Films can play an active role in people's meaning-making processes, because they provide viewers with safe zones in which to explore, reaffirm, or review personal life views. But what is the ethical task of an interpreter in entering the world of another? How perceptive are we in the context of an historic event that shattered humanity's expectations of life? This contextual reflection on the film's main character focuses on the distinctions between mainstream Western interpretations of individual heroism, and courage as part of an inclusive, communal interconnectedness.

\section{The Historical Context of the Film in Brief}

From April 1994, over a 100-day period, about 800000 Rwandese citizens were brutally slaughtered, mostly hacked to death with machetes. For scale and speed, the killings were the most efficient in recorded history. The massacre was perpetrated without any significant intervention from the rest of the world. The film Ghosts of Rwanda suggests that Western politicians such as Bill Clinton, then the President of the United States, and Madeleine Albright, then United States Permanent Representative to the United Nations, among others, knew what was happening, that it was happening on a large scale, and very quickly (Leiner 2014:11). A number of countries called for the withdrawal of their contingents, eventually leaving the United Nations Assistance Mission for Rwanda (UNAMIR) with 270 soldiers, supported by fewer than 200 local authorities. The request from the Commander of the United Nations' peacekeeping force for the immediate insertion of 5000 troops was denied. In effect, the world stood by at the brutal slaughter of a people. 
The history of the Rwandese population in central Africa can be traced back to the ninth and tenth centuries BCE, when the first of three population groups migrated to the area now known as Rwanda. The Twa, hunters and gatherers of the forest, were the first to arrive. They were followed some centuries later by the Hutus, who were farmers and agriculturists. Then, gradually, the pastoralist Tutsis settled in the region between the tenth and fifteenth centuries. These groups coexisted for centuries without large-scale clashes. They spoke the same language, Kinyarwanda, and adhered to the same religion, a belief in one God named Imana (Nzabatsinda 2005:234). They shared many philosophical and literary elements in an oral tradition, the same rituals and a fluid system of social organization: "(A) Tutsi who fell on hard times could become Hutu, and vice versa. There were Tutsi chiefs and Hutu potentates. They also intermarried extensively, so that over time it became increasingly difficult to tell for sure who was what" (Olojede 2004:15). ${ }^{1}$ Both Olojede and Nzabatsinda argue that the distinction between these groups was social, and was informed by financial status rather than by ethnic distinctions in the conventional sense.

According to Dele Olojede (2004), ${ }^{2}$ a focus on ethnic distinctions between Hutus and Tutsis was deliberately cultivated by German and Belgian colonisers from the mid-1880s. At this time, an anthropology of so-called race science was fashionable in Europe. ${ }^{3}$ Germany was initially allotted Rwanda at the 1885 Berlin Conference, which parcelled out Africa among European powers, but Rwanda became a Belgian protectorate after World War I. The Belgians used the ruling elite, the Tutsis, to continue to run the country. When they instituted a system of identity cards that specified each person's ethnicity, it froze every Rwandan's identity, and social mobility was effectively halted. This system remained in place until after World War II, when the Tutsi elite began to demand the end of Belgian colonial rule. The Belgians then shifted their patronage to the Hutu, but in 1959, the Hutu began a purge of the Tutsi from all facets of Rwandan life, a purge that lasted for decades (Olojede 2004:15). ${ }^{4}$

The documentary As we Forgive (2010) voices the perspectives of both perpetrators and victims in the aftermath of the horrors of the Rwandese Genocide of 1994. It reminds us that ordinary people, good people, even (and sometimes especially) those who may be devoted believers, can perpetrate violent and deadly acts. Yet under the harshest of conditions, such as holocausts, there are always some who do not join the masses, but side with the oppressed. In the Rwandan genocide, several accounts tell of people who did not participate in the persecution of Tutsis and moderate Hutus, or even risked their own safety to protect victims. Examples include a small Rwandese Muslim community who saved fellow citizens (Al Jazeera, 15 May 2014), a pastor who hid eight women in his bathroom (Ilibagiza 2006) and Paul Rusesabagina on whom the protagonist in Hotel Rwanda (2004) is based. As a Hutu, married to a Tutsi, according to their identity documents, he saved 1 268 refugees by sheltering them in the four-star Hôtel Des Milles Collines, in Kigali, the Rwandan capital. The hotel was then owned by the Belgian airline, Sabena. Rusesabagina,

This is borne out by the personal account of Immaculée Ilibagiza (2006:20), a Tutsi woman who survived the 2004 genocide.

2 Winner of a Pulitzer Prize for a series of articles ten years after the Rwandese genocide.

3 The sentiment also fuelled anti-Semitism, as is so poignantly portrayed in the Berlin Jewish Museum.

4 The essay "Fear" by Scholastique Mukasonga (2014), for example, recalls her chilling childhood memories of the 1960s and the 1970s, which continue to haunt her today in France. She left Rwanda two years before the mass massacre swept through the country. 
who was the house manager at the hotel, became acting manager when the hotel manager handed him the keys and fled from the upheaval.

\section{Views on Paul as a Hero}

Why does the protagonist in the film Hotel Rwanda (2004) risk his life for others when so many turned their backs on friends, neighbours, family members and an entire people? Kent Williams (2005) is one of several film critics ${ }^{5}$ who compare Rusesabagina's film character with Oscar Schindler in Schindler's List (1993), due to what Williams calls the 'saintly' way in which he protects fellow citizens: "Paul Rusesabagina and his hotel are the very symbol of hope, a beacon of light in a country overcome with darkness" (2005:n.p.). Schindler profited from the German occupation of Poland in World War II, but he also courageously saved more than a thousand Polish-Jewish refugees during the Holocaust/Shoah by employing them in his factories in Krakow. In the same vein, film critic Roger Ebert (2014:n.p.) says that in this tale of heroism and survival, "Rusesabagina rises to the challenge". Leiner defines a hero loosely as "someone - perhaps an ordinary person, or even someone with a dubious agenda - who evolves and displays impressive and ethically good, or even outstanding, behaviour" and he too refers to the example of Schindler. ${ }^{6}$ In terms of his definition he regards Paul as a hero (Leiner 2014:15-17) and the film "a typical hero-story" (Leiner 2014:18,19).

Sakota-Kokot sees Rusesabagina as a black hero, who is "not part of the winning formula of the Hollywood blockbuster" (Sakota-Kokot 2013:225). She points to various notions of othering in the film such as an over-simplified view of the genocide as a barbaric ethnic clash in contrast to (Western) civilisation, a reduction of the Orient or the exotic in an identity of difference, hatred of the excessiveness of the other, and mythical othering whereby the hero needs "exceptional status within the narrative" to be adequately contrasted with the villain (Sakota-Kokot 2013:211-212). Although the film critiques the apathy and the superiority of the West, the sequence of events nevertheless reflects a Western superiority over a stagnant, barbaric, and conservative Africa. She concludes that "Paul is the hero", albeit in a reading of the genocide that "ultimately occurs through Western eyes" (Sakota-Kokot 2013:230) in the way the film deals with ethnicity and historical facts.

Kohen (2010:65) draws on comments by the real Rusesabagina to construct an argument around moral heroism where Paul's circle of care "is expansive enough to include those who are the radically Other". He concludes that Paul's courage stems from being aware of his own mortality, the altruistic example modelled by his father, his disassociation with the Hutu violence and a strong identification with the Tutsi refugees under his protection.

All these critics deem Paul's sheltering of so many people, despite immense pressure from the militia, to be an individual act of heroism in a life-threatening situation. With the exception of Kohen none of them mention the possible roles of communal belonging and interconnectedness. In this regard Kohen (2010:73) notes that according to Paul his

\footnotetext{
$5 \quad$ Similar comparisons are made, for example, in Publishers Weekly (2005:57) and by Ansen (2004:60) and Johnson (2005:52).

6 A hero can also be tragic. It has been a commonplace for more than 2000 years, since Aristotle (ca. 330 BCE), that when a prominent and prosperous person receives undeserved misfortune, for example, it evokes an emotion of pity as a result of a change of fortune from good to bad.
} 
morality has not developed in separation from others, but it was passed on to him by his own father who received it from his father and grandfather and before that from "a mixture of Hutus and Tutsis stretching back hundreds of years". Paul's father was a well-respected person in the Rwandese culture who shared his wisdom in the traditional judicial system of gacaca. To Paul (who does not regard himself to be religious) protecting and housing refugees is part of the Rwandan concept of hospitality and not an unnatural, isolated act of kindness reserved only for friends and relatives. Sheltering and defending strangers is not a nice thing to do, but a spiritual imperative rooted in the Rwandan culture. (Kohen 2010:7274).

\section{Theoretical Differences between a Modern Western View and Interconnectedness}

My focus is on film as a way to deepen an understanding of others and in trying to do so, to choose an appropriate lens to limit othering. The historic context of the Rwandese and the pointers provided by Kohen raise the need to re-view film interpretations that do not take the role of communal belonging into account.

It is very difficult to inhibit projecting one's own existential framework and symbols onto the behaviour of other people, precisely because our experience of these elements are so deep-seated and so ingrained that each of us tends to feel (and think) that her/his own perspective of life is the way things work, or ought to work, for everyone. The elevation of one's own perspective to the decisive or only possible criterion when interpreting another's existential belonging implies an imperialistic approach. For most of us, this is a shocking realisation. Many of us expressly say that we want to do the exact opposite, and claim to have no desire whatsoever to colonise the inner world of others. And still we do it. Time and again I feel embarrassed when I realise in hindsight that I unwittingly projected my own reality view onto those whom I want to understand. Others also step into this trap (Momberg 2010:41-43) or remain perplexed about differences between people.

The social fabric of Rwanda, as in most African countries, was severely distorted by centuries of inappropriate, but active, purpose-driven engagement by European colonialists with the continent and its people in order to shape it according to the material needs, the power bases and the belief systems of Western modernity. ${ }^{7}$ Thus, in considering a film in the context of the Rwandan genocide, the context of centuries of interaction between people from a modern Western-Christian existential paradigm and those from a traditional African existential paradigm needs to be taken into account. ${ }^{8}$

Existential symbols, or our impressions, assumptions, conventions, associations and values, express our interpretation and imagination of various ways to make sense of

Examples of inappropriate engagement in Africa include the slave trade, colonialism and the superficial implementation of nation-state models (Kobia 2003, Clark in Horsfield, Hess \& Medrano, 2004), the effect of the Cold War, the search for natural resources, as well as globalism (Stiglitz 2002).

8 For the purposes of the article, an existential paradigm or a reality view is defined as a quest for, realisation or maintenance of a sense of belonging to a totality, including the ultimately-real (Cumpsty 1991:161). A person's existential paradigm explains how s/he relates to existential features such as the temporary, the spatial and the eternal dimensions of life, the nature of reality, including what is real and what is not, the mode of engagement with the world-out-there, the relationship between an individual and society, chance versus determinism, the attainment of spiritual knowledge, the source of ethics, the ground of meaning, and so forth. Each of these features can be understood or symbolised in different ways by religious traditions and people. I refer to these features as existential symbols. 
totality, including the ultimately-real. For example: Is time perceived as linear or cyclical? Is reality dualistic or monistic? Is the immediate world out there real and ultimate, or not? (Cumpsty 1991:218).

Tarnas (1983:321) argues that the concept of "linear historical progress toward ultimate fulfilment" is "perhaps the most pervasive and specifically Judaeo-Christian component tacitly retained in the modern world view" of Western society. Such a perception of time, with a clear beginning and end (of the world), implies an impetus to work towards a better tomorrow - in other words to shape the environment, one's own life, etcetera, and not to maintain things as they are nor to affirm daily life as of the real and as part of the ultimately-real. Valuing linear time is linked to the expected fulfilment of future events and the individual tends to relate to society in a solidary manner and contributes towards an end point or goal. Sacrifice of the present texture of life and the overcoming of obstacles at great personal cost are regarded worthwhile. Thus an individual may support her/his society in a courageous attempt in solidarity with others, but the motivation for doing so is not necessarily or primarily informed by a sense of communal interconnectedness.

In what may be called an Immediate Experience Affirming a paradigm characterised by interconnectedness plays a significant role. Theoretically and when totally coherent it is characterised by a monistic web of life that connects human beings, nature and the ultimately-real with the past, the present and the future. Each individual is actualised through connection with the community, both those living and those departed. Social relations begin with the individual in the centre and from there move out to a network of relations between the person, the ultimately-real and everything else, but with a decreasing emphasis on the individual. This essentially communal perspective of social relations differs starkly from a modern Western existential paradigm, as the test of the quality of the immediate experience lies in the texture of life and not in goals. Thus the existential value of time is not explained by a series of historical events, but rather by cyclical rhythms as manifested through nature and human life. Change, which is a feature of all life, is not seen as 'going somewhere'. The mode of engagement with the world out there involves fitting into a totality where there is no clear beginning or end, and all are part of a pulsating, coherent whole. Belonging to the ultimately-real is assumed to be axiomatic, and this relation must be maintained or repaired, and not overcome, as it would be in a dualistic, purpose-driven, linear perspective of life (Cumpsty 1991:172-217; Louw 1998; Ukpong 1999; Tarnas 1993).

This paradigm is often associated with the African concept of Ubuntu, "(t)he entire universe participates in the one life of God and there exists a network of relations between God, human beings and the cosmos, with the human being at the center" (Ukpong 1999:112). In this spirituality, every action affects the whole. Every individual belongs to the ultimately-real, or finds existential meaning by belonging to her/his community, as the relationship between God, humanity and nature is interdependent, without a rigid distinction between the personal and the impersonal. The source of ethics is to seek harmony (which requires wisdom). It provides individual purpose, but the individual cannot find meaning or express his or her worth without expressing it through belonging to the community. However Ubuntu and similar terms in sub-Saharan African indigenous cultures can have many different connotations and these have not yet been mapped out (Gade 2012:485-486).

I want to stress that these theoretical outlines of different symbolic expressions (marked by italic print) do not to point to rigid or fixed existential paradigms, but rather to 
distinctions in the interpretations of existential factors and their impact on one another. Although I described some aspects of these two paradigms as if both are coherent, this is often not the case, due to people's personal choices, or to external influences which may result in an uneasy fit between symbols from different paradigms. If we acknowledge that life views are not universal truths, but are expressed rather through a creative imagining of the human condition in the context of the imperceptible (Armstrong 1994:233-234), it should sensitise us not to assume that what identifies or gives meaning to one person automatically applies to everyone else.

In what follows I reflect on the possible roles of both these two paradigms in the film's portrayal of Paul.

\section{Paul's Humanity in a Distorted Society}

When the film starts, the viewer is aware that it is April 1994. Paul Rusesabagina, a Hutu, is portrayed as an aspirational figure in the eyes of his young colleague, the porter Dube:

Dube: Aah, that is a fine cigar, sir!

Paul: This is a Cohiba cigar. Each one is worth 10,000 francs.

Dube: $\quad 10,000$ francs?

Paul: $\quad$ Yes, yes. But it is worth more to me than 10,000 francs.

Dube: What do you mean, sir?

Paul: If I give a businessman 10,000 francs, what does that matter to him? He is rich. But, if I give him a Cohiba cigar straight from Havana, Cuba, hey, that is style, Dube.

Dube: [smiles] Style!

To the admiration of Dube, Paul advises the hotel chef to concoct a dish with local ingredients when the quality of the freshly delivered crayfish is not what is expected. Clad in Western business attire, he is able to befriend and impress Westerners in senior positions, including the Commander of the United Nations peacekeeping force, and he seems to fit seamlessly into the world of European and American officials and tourists. His social standing reflects that of the ruling class in Rwanda, the Hutus, but he is married to a Tutsi woman, Tatiana. Paul navigates between his own political opinion (which opposes the oppression of the Tutsis) and his duty to collect stock for the hotel when he accepts a militia shirt from a Hutu supplier of beer. He talks himself out of the offer to join the militant movement and keeps quiet when a container tips over to reveal machetes instead of crates with beer. On their way back to the hotel, he uses the shirt to pacify Hutu extremists when he and Dube are caught up in a demonstration.

As the political tensions rise, Paul tries to alleviate the anxiety of family members by telling them that there is no reason to leave the country. Shortly after they learn that the Rwandese president's plane has been shot down, ${ }^{9}$ their neighbours are attacked. Paul does not want to call for help when his wife urges him to do so: "All day long I work to please this officer, that diplomat, some tourist to store up favours so if there is a time when we need help I have powerful people I can call upon. [...] He is not family. Family is all that

9 On 6 April 1994, a plane carrying the Rwandan president, a Hutu, was shot down. In the wake of the incident, extremist Hutus from the Interahamwe, a Hutu paramilitary organization, began the killings and implemented a plan to destroy the entire Tutsi civilian population. 
matters." The impression created up to this point is that Paul is successful in the eyes of those who prefer a so-called international (Western) image, and that he distinguishes between himself and his family in relation to others in Rwandese society. Based on the contents of the film thus far, one would suspect that Paul's goal-orientation and his ability to engage actively with and shape his environment to suit his needs can be explained by existential symbols that are generally associated with a modern Western paradigm. It is necessary to allow the story to unfold further before drawing any conclusions.

The next night Paul comes home to find his frightened family hiding with several moderate Hutus in a pitch dark house. He wants to protect only his own family, but his wife Tatiana once more pleads passionately with him to offer shelter to the others too. Paul agrees under pressure and eventually leads the whole group into the Hôtel des Mille Collines after bargaining with a senior member of the Hutu militia, who threatens to kill the whole group, starting with Paul. In the following days and weeks, when the United Nations' refugee camp becomes either too crowded or too dangerous to be safe, more people flee to the hotel. Even in these dire circumstances, whilst coping with an overly full hotel and diverting Hutu soldiers, Paul is always dressed in a neat dark suit with a tie and a spotless white shirt - clothes that differ from the more colourful, African clothes of the rest of the staff. He continues to perform the role of a dedicated manager in effective control of a fully booked hotel, crossing all the t's and dotting all the i's, although his guests are now refugees crowded into rooms. He is depicted as quite as fearful as the others, but, unlike them, he has the means, the skills and the connections to bargain with, and to bribe people with influence, which buys them all time. In short, he is able to shape his environment.

Paul trusts that help will arrive from the Western world, but Jack, a journalist who took video clips of the killings, remarks cynically: "I think if people see this footage they'll say, 'Oh my God that's horrible,' and then go on eating their dinners." When several vehicles with soldiers do arrive at the hotel, it is only to inform them that all Western countries and the United Nations Assistance Mission for Rwanda (UNAMIR) are withdrawing from Rwanda and that all the tourists and officials from Western countries must evacuate immediately. The Commander of the United Nations peace keeping forces shares the journalist's disillusionment of the Western world:

Colonel Oliver: You should spit in my face.

Paul: $\quad$ Excuse me, Colonel?

Colonel Oliver: You're dirt. We think you're dirt, Paul.

Paul: Who is we?

Colonel Oliver: The West. All the Superpowers. Everything you believe in, Paul. They think you're dirt. They think you're dumb. You're worthless.

Paul: $\quad$ I am afraid I don't understand what you are saying.

Colonel Oliver: Oh, come on, Paul, you're the smartest man here. You got 'em all eating out of your hands. You could own this frigging hotel, except for one thing. You're black. You're not even a nigger. You're an African. They're not going to stay, Paul. They're not going to stop this slaughter.

For the first time Paul realises that those he regards as his allies, the very people who inspire him and on whom he relies for help, are not real friends. In a striking symbolic scene in the film, rain pours down as the Western hotel guests, including the press, are accompanied to the rescue vehicles by the staff with umbrellas. Paul, who oversees the 
departure, is drenched. As the buses leave, the hotel staff huddle under the overhang of the entrance and Dube steps forward to offer Paul the shelter of an umbrella. But it is too late. His clothes and his body are soaked from head to toe.

The scene suggests a significant shift or turn in Paul's experience of reality. Liquids or fluids, such as the pouring rain, have multiple symbolic meanings, such as the beginning and end of all things on earth, intuitive wisdom, the mother-imago, the universal congress of potentialities; the female principle and unconsciousness (Cirlot 201:364-367). In this dark moment, Paul experiences an acute personal crisis. He no longer knows where he fits in or what to believe. It is evident that his identification with Western power, style, goalorientation and the ability to shape life are crumbling - he confesses to his wife in a private moment: "They told me I was one of them, and I... the wine, chocolates, cigars, style... I swallowed it. I swallowed it, I swallowed all of it. And they handed me their shit. I have no... no history. I have no memory. I'm a fool, Tati." With the Western peacekeeping forces and hotel guests all gone, Paul encourages the displaced to save themselves by phoning influential people abroad and asking for help with repatriation.

It is only when, in a nauseating scene, he physically experiences the unacceptability of his changed life-world as a result of the brutal murders that he can no longer sustain his suit-and-tie image and is stripped to his core. Late one afternoon, an unwilling Dube accompanies Paul to one of the hotel's suppliers in order to secure food for the refugees. When they return with their load, it is already dark. They take the same road that they had travelled that afternoon. At some point, the vehicle appears to be off the road, bumping over what seem to be rocks. Paul, tense, shouts at Dube to get the vehicle back on the road immediately. What they subsequently discover strips Paul of all visible signs of control. The road, which was deserted and clear a few hours ago, is now littered with lifeless, massacred bodies, impeding the vehicle's progress.

Back at the hotel and in the privacy of his bathroom, the viewer sees an utterly distraught man. Once more the film uses water as a symbolic medium to connect deepseated feelings with Paul's present reality. After a shower to rinse off the blood and grit on him as a result of clearing the road of dead bodies, Paul dresses himself afresh in a stark white shirt and begins to put on a tie. But this time he cannot go through with it. He can no longer cover up. "Immersion in water signifies a return to the pre-formal state, with a sense of death and annihilation on the one hand, but of rebirth and regeneration on the other, since immersion intensifies the life-force" (Cirlot 2001:365). Thus far, Paul has acted purposefully and tried to shape the hotel full of refugees to resemble a well-managed business. Now it seems as if the very foundation of his beliefs has been shattered, and he can no longer maintain his carefully collected image. The acute horror of the massacre amongst his people has been brought home to him in a brutal and literal way. The overwhelming anguish strips his identity of its outer layers and levels him. With his back pressed against the bathroom wall, the utterly distressed man slides down to the floor, tearing the clean, white shirt and tie from his body to reveal the dark skin of his torso. The viewer sees a man crawling on the floor, gasping in anguish. Someone knocks on the door, but he cannot open it. In this moment, he is no saviour, he has no hope and he feels helpless. He grapples with himself and with what makes life worthwhile. Those whom he trusted have deserted him and his country, and his own people are murdering their fellow citizens. How can he make sense of all this? He experiences more than horror - it is a spiritual crisis. 
The shower and the blood, or the second immersion in fluids, seems to stir his consciousness to a point where he rediscovers the life-force of his communal Rwandese roots. The viewer meets Paul as someone interested only in his own family's safety in the opening scenes of the film. When his wife pleads with him to shelter the victims, he eventually tries to please her. However, Tatiana's heart-rending requests, together with Paul's own disillusion and trauma prompt a re-awakening of a deep-seated, felt sense of reality based on a centred communal belonging in him. After the dramatic scene in the bathroom, the portrayal of Paul's social values no longer represents any traces of an individual perspective, but he actively extends his personal position or individual centre to encompass the displaced. He no longer wears a suit and a tie. Some of the calls by refugees for help pay off, and they, including the Rusesabagina family, are granted permission to be evacuated to other countries. Yet many are not that lucky. As Paul is about to get into the rescue vehicle, he turns around to look back at those whom he has just greeted, and realises that he cannot leave them. In what may seem like a heroic deed to the Western mind, he forsakes his personal chance to freedom by sending his wife and children and the others to safety, while he stays behind to take care of those who are not yet on the evacuation list. Yet, if in the deepest sense, the integrity of his own existence is meaningful when he realizes himself through communion with others, it means that his choice to remain behind is not a heroic deed in the classic Western sense, but a profound, inclusive expression of humanity within a spirituality of interconnectedness.

The words of emeritus Archbishop Desmond Tutu (2000:31), "I am human because I belong, I participate, I share" and "(s)ocial harmony is for us the summum bonum - the greatest good" come to mind. As such the source of ethics - that which governs relationships with people and the world - is not a higher realm or a future goal, but an integrated part of a "network of interdependence and togetherness" (Tutu 2000:166) or "the bundle of life" (Tutu 2000:196). Or as explained in the words of Ma'Makhubu - the mother of the boy who carried the dead body of Hector Petersen during a 1976 student protest against South African apartheid: "Mbuyisa is or was my son. But he is not a hero. In my culture, picking up Hector is not an act of heroism. It was his job as a brother. If he left him on the ground and somebody saw him jump over Hector, he would never be able to live here." In this sense the social ethos is not symbolised by a solidary act of rescuing others, but by affirming the relations between the living and the dead. Tutu's remarks on South African Ubuntu express an inclusive morality that values all persons as interconnected and human, and Ma'Makhuba's words point to a moral duty of "I can do no other" that is not special, but natural even when people flee for their lives. In the same vein, Paul's act may express, affirm and perhaps restore some sense of human dignity in the desperate situation as a result of his inclusive, expansive understanding of the Rwandese notion of hospitality and brotherhood.

In the scenes that follow, the situation intensifies. The United Nations vehicles with his family and refugees are attacked and they have to return to the hotel. Paul has nothing left to buy time with, not even one day. The present is a dark pit of utter devastation, and there is no future. They have nowhere to go, and no-one to protect them. The possibility of life implodes. It seems as if individual survival becomes the very factor which is required for meaning. All that "remains as a possible ground of meaning is individual contributions to a struggle for short-term sectional improvements in texture" (Cumpsty 1991:205). Cumpsty argues that in such a situation, the 'grand design' which is expressed either by major

10 Ma'Makhubu's words are inscribed at the Hector Petersen Memorial in Soweto, South Africa. 
supportable goals or in the worthwhile texture of daily experiences as in an Immediate Experience Affirming paradigm, is missing. In this case, neither modern Western existential symbols of solidarity, an active shaping of the world out there, sacrifice and goal-orientation, nor symbols such as communal social values, wisdom, the restoration of harmony and an emphasis on the quality of the experience, can bring relief.

Whether Cumpsty's comments apply or not in this case is not clear from the last scenes. The film concludes as the Rusesabagina family and everyone else in the hotel reach safety in a United Nations refugee camp. In a post-script, the viewer is informed that the Rusesabagina family relocated to Belgium after the genocide. How they and all the Rwandese - both those who survived the massacre and those who participated in the killings - cope with life and find existential meaning and belonging after the genocide may be a story that is still unfolding.

\section{Conclusion}

Paul Rusesabagina's character portrays both the positive and traumatic effects of a severely damaged tapestry of society, where two existential paradigms, each with different sets of aspirations and symbolic expressions, co-exist in incoherent ways as a result of centuries of Western intervention.

In the film Paul develops from a person who pursues his own interests to someone who risks his life for the sake of others. To interpret his behaviour as heroic, or as resembling those of Oscar Schindler, may reflect a modern Western view, if it is assumed that he overcomes a current reality too devastating to be confirmed as the ultimate in his striving for a better tomorrow. Such an interpretation of courage and sacrifice, hailed for being special in society, is devoid of a relevant, and additional, perspective of an interconnected societal bond that needs to be affirmed and restored for the sake of the spiritual wellbeing and worthwhileness of the individual as an integral member of the community.

Hotel Rwanda (2004) portrays a haunting, true tragedy and the human potential to live with spiritual integrity in the absence of hope for physical survival. If it is the ethical responsibility of a film critic to focus, first and foremost, on the portrayal of the film character and not on the self, it is perhaps not too much to ask to consider symbols from different existential paradigms in the historic context of the film. To reduce someone else to the way I understand life without even trying to engage with the other's world, may perpetuate neglect, exclusion and othering. In this case, it would compound the human tragedy that Hotel Rwanda (2004) urges us to not forget or repeat.

\section{BIBLIOGRAPHY}

Al Jazeera English. Hutu Muslim saved Tutsis during Rwandan Genocide. YouTube video clip. [Online]. Available: http://www.dailymotion.com/video/xqlmqy_hutumuslims-saved-tutsis-during-rwandan-genocide-8-apr-09_news. [2014, 15 May].

Ansen, David 2004. A hero will rise. Newsweek, 144(25):60. Film review. [Online]. Available: http://web.b.ebscohost.com.ez.sun.ac.za/ehost/ detail/detail?vid=7\& sid=d799e1f4-e11f-4051-881f-d2e8a1a4a499\%40sessionmgr113\&hid=125\&bdata =JnNpdGU9ZWhvc3QtbGl2ZSZzY29wZT1zaXRl\#db=aph\&AN=15343414. [2015, 24 August]. 
Armstrong, K 1994. A History of God. The 4 000-year quest of Judaism, Christianity and Islam. New York, NY: Ballantine.

As we forgive 2010. Documentary. Directed by: Laura Waters Hinson. Narrated by: Mia Farrow. Music by: Chris Biondo, Lenny Williams. United States of America. 53 mins. Produced by: Laura Waters Hinson.

Cirlot, Jacques E 2001. A Dictionary of Symbols. Trans. J Sage. London: Routledge.

Cumpsty, JS 1991. Religion as Belonging: A General Theory of Religion. Lanham, MD: University Press of America.

Ebert, R 2004. Hotel Rwanda. Film review on rogerebert.com. [Online]. Available: http://www.rogerebert.com/reviews/hotel-rwanda-2004 [2014, 21 July].

Gade, C 2012. "What is Ubuntu? Different Interpretations among South Africans of African Descent." South African Journal of Philosophy, 31(3):484-503.

Horsfield P, Hess, ME \& Medrano, AM (eds.). 2004. Belief in Media. Cultural Perspectives on Media and Christianity. Aldershot, UK: Ashgate.

Hotel Rwanda 2004. Directed by: Terry George. Written by: Keir Pearson, Terry George. Performed by: Don Cheadle, Sophie Okonedo. United Kingdom, United States, Italy, South Africa. 121min. English, French. Produced by: Lions Gate Entertainment, United Artists.

Ilibagiza, I 2006. Left to Tell: Discovering God amidst the Rwandan Holocaust. Carlsbad, CA: Hay House.

Johnson, Brian D 2005. Reviews the motion picture "Hotel Rwanda" starring Don Cheadle. Maclean's, 118(2):52. 1/3p. 1 Color Photograph. [Online]. Available: http://web.b.ebscohost.com.ez.sun.ac.za/ehost/detail/detail?vid=5\&sid=6439961a2523-4585-baace8edc80a08b4\%40sessionmgr115\&hid=125\&bdata=JnNpdGU9ZW hvc3QtbG12ZSZzY29wZT1zaXRl\#db=buh\&AN=15577882. [2015, 24 August].

Kobia, S 2003. The Courage to Hope: The Roots for a New Vision and the Calling of the Church in Africa. Geneva: WCC.

Kohen, A 2010. “A Case of Moral Heroism: Sympathy, Personal Identification, and Mortality in Rwanda." Human Rights Review, 11(1):65-82. [Online]. Available: http://web.a.ebscohost.com.ez.sun.ac.za/ehost/pdfviewer/pdfviewer?vid=32\&sid=ad dbf1ee-f964-4ea3-84c3-e9692d16f368\%40sessionmgr4005\&hid=4201.

Leiner, M 2014. Films about the Genocide in Rwanda 1994 - An Example of the Moral Landscape Method (MLM) in Media Analysis. Paper presented at Department of Systematic Theology, Stellenbosch University, Stellenbosch, February 14.

Louw, D 1998. Ubuntu: An African Assessment of the religious Others. Paper presented at the Twentieth World Congress of Philosophy, Boston, MA, 10-15 August. [Online]. Available: http://www.bu.edu/wcp/Papers/Afri/AfriLouw.htm. [2012, 25 January].

Momberg, MJ 2010. Different Ways of Belonging to Totality: Traditional African and Modern Western Cosmologies in Three Films. An Exploratory Study. MPhil thesis. Stellenbosch: Stellenbosch University. Available: http://scholar.sun.ac.za/handle/10019.1/17. [2011, 31 January].

Mukasonga, S 2014. Fear. Trans. M Mauthner. In Imagine Africa. Cape Town: Pirogue, Island Position. 
Nzabatsinda, A 2005. Hotel Rwanda. Research in African Literatures, 36(4), Winter:233236. [Online]. Available: http://content.ebscohost.com.ez.sun.ac.za/ pdf25_26/pdf/2005/RAL/01Dec05/19013564.pdf?T=P\&P=AN\&K=19013564\&S=R $\& \mathrm{D}=$ aph \&EbscoContent=dGJyMNLe80Sep7M4y9f3OLCmr0yeprJSsau4S7OWxW XS\&ContentCustomer=dGJyMPGqsEq0rrVPuePfgeyx44Dt6fIA. [2014, 15 May].

Olojede, D 2004. History of a Deadly Divide. Newsday. May 2, 2004. Part of a series of articles awarded the Pulitzer Prize, E-mail to M Momberg. (14953609@sun.ac.za).

Publishers Weekly 2005. Hotel Rwanda: Bringing the True Story of an African Hero to Film, Publishers Weekly, 252(6):57. 1/4p. Book review. [Online]. Available: http://web.b.ebscohost.com.ez.sun.ac.za/ehost/pdfviewer/pdfviewer?vid=6\&sid=d79 9e1f4-e11f-4051-881f-d2e8a1a4a499\%40sessionmgr113\&hid=125. [2015, 24 August].

Schindler's List 1993. Directed by: Steven Spielberg. Written by Steven Zaillian. Performed by Liam Neeson, Ben Kingsley, Ralph Fiennes, Caroline Goodall, Embeth Davidtz. United States. 195min. English, Hebrew, German, Polish, French. Produced by: Steven Spielberg. Universal Pictures.

Sakota-Kokot, Tanja. 2013. When the past talks to the present: Fiction narrative and the 'other' in Hotel Rwanda. Critical Arts: A South-North Journal of Cultural \& Media Studies, 27(2):211-234. [Online]. Available: http://web.b.ebscohost.com.ez.sun.ac.za/ ehost/pdfviewer/pdfviewer?vid=4\&sid=d799e1f4-e11f-4051-881fd2e8a1a4a499\%40sessionmgr113\&hid=125. [2015, 24 August]

Stiglitz, JE 2002. Globalization and its Discontents. London: Penguin.

Tarnas, R 1993. The Passion of the Western Mind. New York, NY: Ballantine.

Tutu, D 2000. No Future without Forgiveness. London: Rider.

Ukpong, JS 1999. Towards a Holistic Approach to Inculturation Theology. MissionStudies, 16(2):100-124.

Williams, K 2005. Hotel Rwanda. Review on Isthmus. The Daily Page. [Online]. Available: http://www.thedailypage.com/isthmus/article.php?article=3710. [2008, 26 June]. 